\title{
Haloaerosoltherapy: Mechanisms of Curative Effect and Place in the Respiratory Rehabilitation
}

\section{LEMKO Olha, LEMKO Ivan}

Editor: Constantin Munteanu, Romanian Association of Balneology,office@bioclima.ro

Reviewers: Silisteanu Sinziana Calina and Rotariu Mariana

*Corresponding author: LEMKO Olha, E-mail: $\underline{\text { o.i.lemko@gmail.com }}$

Government Institution "The Scientific-practical Medical Centre "Rehabilitation"

Health Ministry of Ukraine", Uzhhorod, Ukraine

\begin{abstract}
Introduction. Management of patients with chronic pathology requires development of long-term programs with organic combinations of medicamental and non-medicamental influences. Haloaerosoltherapy is a group inhalation of rock salt aerosol with concentration of more than $2-3 \mathrm{mg} / \mathrm{m}^{3}$ and certain dispersion (with presence of large-, medium- and small-grained aerosol) aboveground.

Material and method. On the basis of literature data review and results of own researches a comprehensive description of haloaerosoltherapy, its mechanisms, available technologies, indications and effectiveness at pulmonary pathology was given. Results and discussion. Basis of haloaerosol curative influence is hyperosmolar stimulus that improves drainage function of bronchi and provides sanitizing effect, which causes further changes at local and systemic levels. This justifies haloaerosoltherapy usage as method of rehabilitation treatment. Comparison of haloaerosoltherapy and other methods of halotherapy (use of halite), in particular, "salt rooms (caves)" was made. It has been proven that "salt rooms" can be used only as spa procedure.

Conclusions. Application of term "halotherapy" to all methods that use halite or underground treatment is incorrect. This determines necessity for stop using this term. It is necessary to differentiate clearly applied methods of treatment using terms that reflect the essence of therapeutic effect. Haloaerosoltherapy should be considered a method of respiratory rehabilitation with a proven mechanism of action and effectiveness. Haloaerosol is obtained using specific devices - halogenegenerators. The effectiveness of haloaerosoltherapy immediately after the course of treatment and in remote period is testified.
\end{abstract}

Keywords: Respiratory rehabilitation, halotherapy, haloaerosoltherapy, speleotherapy,

\section{INTRODUCTION}

Management of patients with chronic pathology requires treatment not only in the acute period, but also needs development of treatment programs beyond the period of exacerbation, aimed at the stabilization of pathological process, prevention of the exacerbations' recurrence and progression of the disease. Long-term management programs for patients with chronic diseases should be based on a rational combination of basic medicamental treatment and various non-medicamental influences that organically complement each other. In particular, in the rehabilitation of pulmonary patients, methods that help the patient get rid of bad habits (smoking), give psychological support are used, training programs for patients are developed, physical training, respiratory physiotherapy are recommended etc.

Speleotherapy and halotherapy are among the methods already used as means of respiratory rehabilitation. However, in most cases, the medical community does not have a clear understanding of the peculiarities of these methods' influence and their possibilities. In our previous works, we have already tried to differentiate the varieties of these techniques and indicate their place in the system of pulmonary rehabilitation. In particular, article published in the journal "Asthma and Allergy" [1] is devoted to speleotherapy, highlights the mechanisms of its influence on the human organism, clearly emphasizes that speleotherapy is the usage for therapeutic purposes karst caves and mine workings (most often salt). Therefore, a mandatory component of such treatment is the stay of patients for some time in underground conditions, and any treatment or prevention technologies carried out aboveground have no speleotherapeutic effect and cannot be called speleotherapy.

In our next publication [2] the questions of development of "artificial analogues of speleotherapy" were considered. These analogies describe methods of influence, which try to imitate some factors of underground conditions, various techniques that relate to halotherapy (halite - mineral of sodium chloride). The term "halotherapy" was proposed by Pavel Gorbenko in 1985 to describe methods of above-ground use of halite in form of dry aerosols [3]. Based on the analysis of literature data, it was proved that most rational is usage of dry aerosols of rock salt (haloaerosols) with certain characteristics of concentration and dispersion. Two terms were proposed to use: haloaerosoltherapy - the therapeutic use of aerosol media of rock salt as a group inhalation, and haloinhalation therapy individual inhalations of dry haloaerosols or wet inhalations of sodium chloride solutions. Numerous studies also prove that 
the usage of "salt rooms (caves)", in which the walls are covered with salt, but without halogenerators (devices that create aerosol media of rock salt) have no therapeutic effect in pathology of bronchopulmonary system and upper respiratory tract and can be used only as a spa treatment [4-7].

The aim of the study - on the basis of literature data review and results of own researches to give a comprehensive description of haloaerosoltherapy, mechanisms of its influence on the human organism, available technologies of procedures, indications for use and effectiveness at pulmonary pathology.

Scientific basis of the method. Scientific investigations concerning development of treatment methods that could to some extent imitate therapeutic effects of salt mines proved that today the only such factor is creation of dry aerosols of rock salt. By haloaerosoltherapy (HAT) we mean the usage of dry aerosol media of rock salt with certain parameters of concentration (not less than $2-3 \mathrm{mg} / \mathrm{m}^{3}$ ) and appropriate dispersion in the form of group inhalations, which are created using special devices - halogenerators.

From the very beginning, physicochemical investigations and study of certain parameters of dry haloaerosol were of great importance in the development of HAT method and especially in substantiation of haloaerosol usage. These investigations were originated from the study of speleotherapy mechanisms. It was proved that the peculiarities of crystal structure of the dispersed phase of haloaerosol provide certain active properties and increase effectiveness of its influence [8], and certain physical parameters (surface energy, negative charge, concentration) play a leading role in providing antibacterial and hypoallergenic environment [4,9]. It was shown that the efficiency of air purification depends on the concentration of haloaerosol and increases in proportion to its level [9]. The importance of nanostructure of the dispersed phase of haloaerosol is also pointed out by other researchers [10].

In addition, based on detailed studies of the physical and chemical properties of different types of rock salt, it has been proved that not every salt can be used equally successfully to create aerosol media, and the origin (source) of the salt should be considered as the most important factor [5,10,11]. Polish scientists have proved that the higher is the content of insoluble components in salt, the less suitable it is for creation of aerosol media. Among the studied varieties of rock salt in Poland (Wieliczka, Bochnia and Kłodowa deposits), the best, in their opinion, is salt from Kłodowa deposit, which contains $95 \% \mathrm{NaCl}$ and has a high iodine content $(6,7 \mathrm{mg} / \mathrm{kg})$ that increases its value [11]. In addition, researchers stated that Dead Sea salt obtained by evaporating of seawater is not suitable for creating dry aerosol media.

At the same time, it should be noted that rock salt of the Solotvyno deposit (Transcarpathian region of Ukraine) contains 98\% $\mathrm{NaCl}$ and different microelements (magnesium, potassium, calcium) [1,8], which may play certain role in metabolic processes, although these questions have not been studied in detail.

There is also the question of possibility of "salt load" during haloaerosoltherapy procedures. Polish researchers have calculated that during the procedure with dry haloaerosol concentration of $10-15 \mathrm{mg} / \mathrm{m}^{3}$, which is most often used, the patient receives on average only about $13 \mathrm{mg}$ of sodium chloride, which cannot adversely affect patient's organism [11,12]. However, it should be noted that as the concentration of haloaerosol increases, the dose of sodium chloride entering the patient's organism may be elevated. This requires a balanced approach, taking into account peculiarities of pathological process and presence of comorbid pathology.

Technology of haloaerosol procedures. The key point in the creation of aerosol media is functioning of halogenerator and possibility for dynamic control over parameters of generated therapeutic haloaerosol. The first halogenerator was developed by scientists in Uzhhorod (Ukraine) in 1982 [13]. However, it was not possible to create the desired haloaerosol concentration and dispersion. Today, a new type of halogenerators has been developed, in which mechanical grinding of salt is combined with simultaneous separation of obtained particles, which makes it possible to generate haloaerosols with different dispersion and achieve their high concentrations [14-15]. In particular, according to different investigations, the concentration of haloaerosol depending on the characteristics of the halogenerator can range from $3-4 \mathrm{mg} / \mathrm{m}^{3}$ to $90 \mathrm{mg} / \mathrm{m}^{3}$ $[4,11,16]$. The most commonly used concentrations of haloaerosol are up to $15 \mathrm{mg} / \mathrm{m}^{3}$, which can be used for both therapeutic and prophylactic purposes [9,17-19]. The use of haloaerosol media at higher concentrations is possible only for therapeutic purposes, according to careful analysis of comorbidities and development of appropriate procedure technologies [7,15,20-22].

A special laser-optical system was also developed that can work in aggressive rock salt environment and measure the concentration of aerosol and its dispersion. This allows to control the process of creating aerosol environment, changes of its parameters during the treatment process and to create aerosol environments with specified parameters $[15,23,24]$.

Besides the concentration of haloaerosol, other parameters are of significant importance in the assessment of treatment environment, in particular questions of room ventilation and bacterial contamination. Unfortunately, these requirements are not clearly regulated. Regarding the size (volume) of the room where procedures are performed, in most cases standard of 3$6 \mathrm{~m}^{3}$ of air volume per patient is used. A comfortable air temperature $\left(20-23^{\circ} \mathrm{C}\right)$ at humidity of $40-60 \%$ are recommended. However, the last two parameters of conditions above-ground significantly depend on weather factors $[3,25$ 27].

The initial overall bacterial contamination of air in treatment rooms for haloaerosolthery (with permanent use of halogenerator) does not exceed 100 microbial bodies per $1 \mathrm{~m}^{3}$, and after the procedure the microorganisms concentration doubles [25,28]. In "Halotherapy salon" (Romania), where halogenerator does not work during all procedures, the background concentration of bacteria in the air is 197-300 per $1 \mathrm{~m}^{3}$ [29], and in "sylvinite speleoclimatic chamber" (Russia), in which none halogenerator is used, this value reaches 800 microbial bodies per $1 \mathrm{~m}^{3}$ [30]. This fact once again emphasizes the role of appropriate concentrations of haloaerosol in purification of air from bacterial contamination.

Thus, the main active factor of HAT is a haloaerosol of certain concentration (not less than $2-3 \mathrm{mg} / \mathrm{m}^{3}$ ) with certain sizes of dispersed phase $[7,11,17]$. Aerosol particles with a size of 2$8 \mu \mathrm{m}$, which influence all parts of bronchial tree, are of leading importance. Their relative content should be $70-80 \%$. The 
larger aerosol particles settle in upper respiratory tract, causing appropriate clinical effects and can be used in some ENT pathology. The dispersed phase of aerosol less than $1 \mu \mathrm{m}$ does not remain in the airways, and therefore does not provide hyperosmolar stimulation, which is the basis of the mechanism of haloaerosol influence and, therefore, can not have therapeutic effect $[5,7,11,31]$. It is also necessary to control sanitary and hygienic indicators, first of all bacterial air pollution. All other characteristics are additional and do not play a significant role in the treatment process.

During the course of HAT, two periods are distinguished: adaptation period and main treatment period. The necessity for adaptation period at the beginning of treatment is conditioned by irritating effect of haloaerosol on the respiratory tract mucosa. It includes 3-4 procedures with gradual increase in its duration: for adults - 15-30-45-60 minutes; for children 10-20-30 minutes. The main treatment period includes daily HAT seances with maximum duration of 60 minutes for adults and 30 minutes for children [18-20,27]. That is, duration of one procedure is determined by patient's age, peculiarities of disease, its severity, presence of comorbid pathology and possible influence of HAT on it, as well as some other modifying factors. In particular, for patients with COPD two daily seances of HAT for 30 minutes each, with an interval of 3-4 hours are used. This is due to fact that first $30 \mathrm{~min}$ of the procedure is the period of maximal concentration of haloaerosol, which increase the intensity of haloaerosol influence, on one hand, and on the other - 3-4 hours interval helps to avoid severe balneological reactions [31].

Mechanisms of therapeutic effect. The basis of haloaerosol influence is a hyperosmolar stimulus, which is realized primarily in improving the rheological properties of sputum and stimulating the ciliated epithelium, which leads to increased mucociliary clearance and bronchial drainage function (Fig.1) [10,22,32].

Distinct manifestation of this clinical effect is realized beginning with the $3-4^{\text {th }}$ procedure in both adults and children with bronchopulmonary pathology and is described by almost all researchers who analyze condition of patients during HAT [4,9,18,21,28,33-35]. Increased sputum discharge is accompanied by some usual natural deterioration of bronchial patency, which is manifested clinically in cough increasing, may be associated by increase in wheezing and confirmed by changes in spirometric pulmonary function test (PFT) [34-37].

In particular, S.F.Goncharuk et al (2006) [36] according to the results of dynamic control of external breething function indices during the course of HAT revealed that in children with bronchial asthma after the first five procedures there is a tendency for reducing the integrated rate of bronchial patency (forced expiratory volume by the first second - $\mathrm{FEV}_{1}$ ) and significant decrease in the patency of small bronchi. Procedures were performed daily, except weekends at haloaerosol concentration of $12-14 \mathrm{mg} / \mathrm{m}^{3}$. Subsequently, by the $10^{\text {th }}$ procedure, all indices increased. Authors also noted that some indices increased significantly only up to the $15^{\text {th }}$ procedure, and largest value of vital capacity was registered for the $20^{\text {th }}$ procedure. This study on one hand clearly confirms effect of HAT on bronchial drainage and presence of balneoreactions during treatment, and on the other substantiates the duration of treatment and breaks down all "commercial" approaches to prescribing short courses of HAT (less than 10 procedures even for children).

These data were also confirmed by results of examination of children with recurrent bronchitis aged 5-10 years and category of frequently ill children (more than 4 episodes of acute respiratory diseases (ARD) during a year) [21,37]. In these children from the second to the tenth HAT procedure manifestations of rhinitis and increased wet cough were observed, but without signs of ARD. This was regarded as a reaction of mucosa of ENT organs and respiratory tract to the dry haloaerosol. It should be emphasized that significant increase of morning and evening peak flow data was registered only from the $10^{\text {th }}$ day of treatment.

Similar regularities were observed in dynamic (weekly) registration of spirometric PFT indices in adult patients with bronchial asthma [27]. It was found that indices of spirometric PFT reach a maximum in the third week of treatment $\left(15^{\text {th }}-16^{\text {th }}\right.$ procedure of HAT) and then increased less markedly. That is, minimal number of procedures per course of treatment for adults and children with asthma should be at least 15-16, and for the category of "frequently ill children" - 13 seances, accounting additional prescription of certain other physiotherapeutic procedures [20].

Balnelogical reactions that occur during HAT, which is performed according to the technology of procedures, are usually mild or moderate. They may be accompanied by shortterm (within 2-3 days) increase in the frequency of rescue medications (inhaler) use by patients with moderate or severe bronchial asthma or COPD, but as a rule do not require another additional precriptions. During bronchial tree clearing, clinical manifestations become less intensive, which is confirmed by appropiate functional studies [21,34-37].

It is also considered that haloaerosol causes/intensifies elimination of biologically active substances, which helps to reduce or stop bronchospasm and, consequently, improves bronchial drainage, reduces bronchial obstruction and is accompanied by decrease of histamine level in blood [9,10,38,39].

Moreover, haloaerosol provides bactericidal effect, which has been proven by experimental and clinical investigations $[10,25,40]$. In particular, it was demonstrated in experiment that dry highly dispersed aerosol has inhibitory effect on the growth and viability of microorganisms, changes their biological properties [41]. At the same time, there was elevation of electrophysiological functional activity of epithelial cells and increase of their colonization resistance, which indicates improvement of protective properties of respiratory tract cells.

In addition, in frequently ill children of two age groups (7-10 years and 11-15 years) the morphofunctional status of oropharyngeal mucosa with determination of cell composition, character of biocinosis and colonization activity of pathogenic and opportunistic microflora were studied $[42,43]$. In treatment of children HAT was used with haloaerosol concentration of 3 $4 \mathrm{mg} / \mathrm{m}^{3}, 10$ procedures per course of treatment (procedures were performed daily for two weeks except weekends). Improvement of the studied parameters were detected. According to researchers, these changes indicate signicant bacteriostatic and sanogenetic effect of haloaerosol, although duration of treatment course (10 procedures) accounting the 
dynamics of spirometric PFT indices should be considered insufficient. Sanitizing effect in combination with increased bronchi drainage function leads to decrease of inflammatory process activity in bronchi and is accompanied by improvement of mucosal immunity and reduced bronchial hyperactivity.

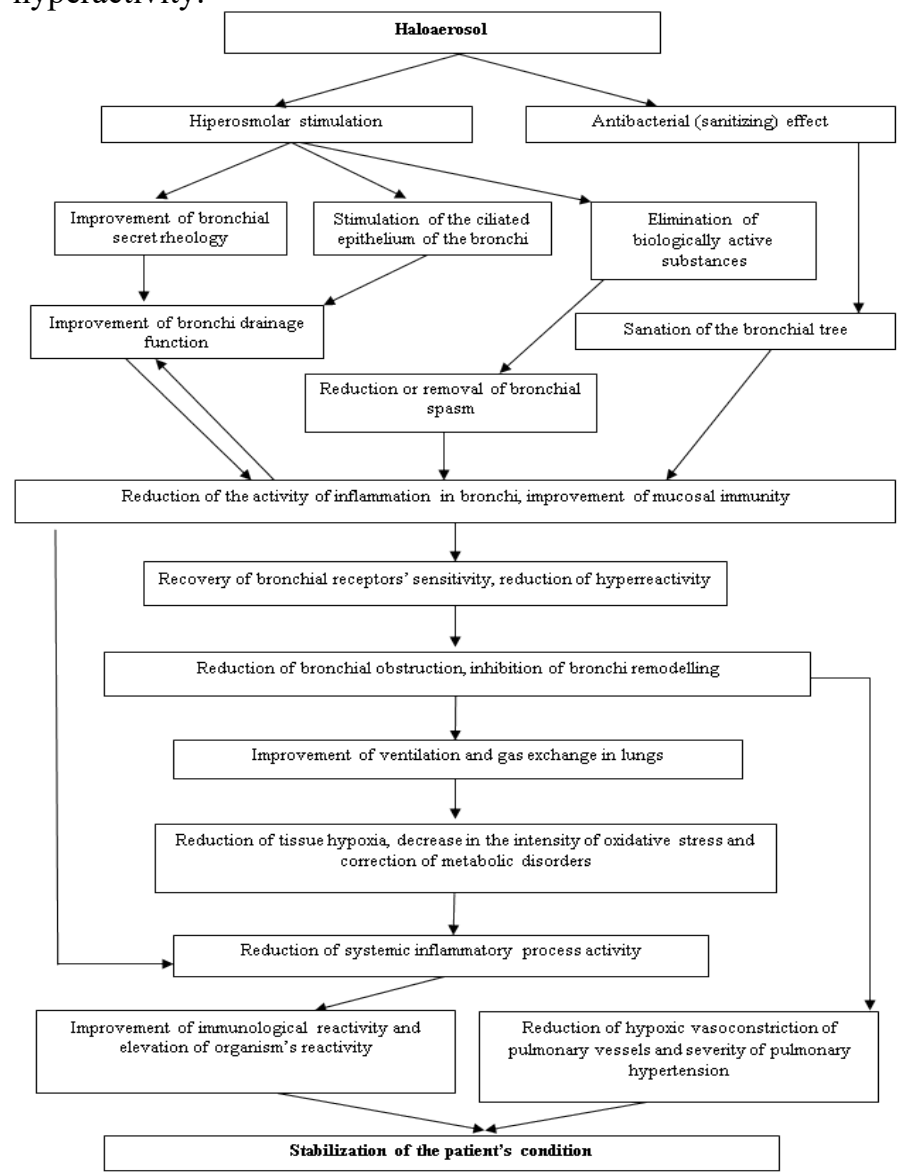

Fig. 1. Mechanisms of curative influence of haloaerosoltherapy The activity of inflammatory process in bronchial tree has been precisely studied in patients with COPD of different severity and under the influence of different treatment regimens. Cellular composition of sputum was studied, as well as content of lipid peroxidation (LPO) products and stable metabolites of nitric oxide (NO), interleukin-8 (IL-8) in exhaled air condensate and serum [44-47]. It was testified that positive changes of these indices at the local level are more intensive than at systemic one. This confirms significant local effect of HAT with controlled concentration and dispersion of haloaerosol and its therapeutic effect at COPD patients in general. Expressiveness of these changes during HAT procedures with increased intensity of aerosol influence is more significant $[19,44,46]$.

The decrease of local inflammatory process activity in bronchi under the influence of HAT was also proved on the basis of NO levels study in exhaled air (FeNO) in children with bronchial asthma [6]. Moreover, authors compared effectiveness of treatment with the usage of halogenerator and in the "salt room" without usage of such device and noted positive dynamics only when using halogenerator.

Improvement of mucosal immunity indices under the influence of HAT was analyzed in details at frequently ill children. Normalization of secretory immunoglobulin A ( $\operatorname{sgA}$ ) levels in saliva at these children were revealed $[42,43]$. In patients with COPD, dynamics of these changes is less expressed and depends on the disease's severity [19].

Reducing of bronchial hyperreactivity in patients with bronchial asthma is of particular interest and has been noted by a number of researchers $[6,33,48,49]$. They are unanimous in testifying that reduction of bronchial hyperreactivity in patients with bronchial asthma under the influence of HAT occurs. Some of them [6,33] associate this effect with decrease of inflammatory activity in bronchial tree, and others [49] do not find such relationship, but in the latter case, course of treatment was only 10 procedures.

Experimental studies have also been conducted on mice, which prove presence of link between decrease in bronchial hyperreactivity and decrease in proinflammatory cytokine levels and inflammatory activity in bronchi under the influence of inhalation of brine from Wieliczka (Poland) [50].

Recovery of sensitivity to basic bronchodilators $\left(\beta_{2}\right.$-agonists and cholinolytics) is very important in the management of patients with bronchial asthma and COPD. In this aspect reduction of frequency of rescue medications usage is actual, which is often combined with decrease in the dose of basic drugs, and these changes take place on the background of improved spirometric PFT indices and clinical course of disease [22,27,51]. In particular, at patients with persistent bronchial asthma analysis of changes in the frequency of rescue medications ( $\beta 2$-agostists) usage and changes in PFD data under the influence of HAT depending on disease's severity and treatment regime was conducted. It was shown that under the influence of all treatment regimes frequency of rescue medications daily use is reduced in 1,4-2,7-4,3 times. It is most expressed while using treatment complexes with increased haloaerosol intensity, when indices of spirometric PFD significantly increased by $10-15 \%$ [22]. It was also noted that among patients who, according to functional tests with bronchodilators before treatment, were insensitive to neither $\beta_{2}$-agostist nor cholinolytic (iprotropium bromide), in $60-67 \%$ of cases, sensitivity to at least one of them recovered. These changes depended on HAT regime and significantly increased effectiveness of basic treatment. After the course of HAT only $30-40 \%$ of patients remain resistant to bronchodilators, which determines the necessity to find other mechanisms of bronchial obstruction.

Due to decrease in the activity of local inflammatory process in bronchi, which is accompanied by recovery of receptor apparatus sensitivity, decrease in bronchial obstruction was observed. These factors in complex contribute to inhibition of bronchial remodeling processes and are, above all, actual for COPD patients. Decrease in bronchial obstruction is manifested by elevation of ventilation indices and is noted by all researchers while using HAT, ie when using aerosol media of rock salt, created by halogenerator with observance of requirements for concentration $\left(>2-3 \mathrm{mg} / \mathrm{m}^{3}\right)$ and appropriate dispersion [52]. The expressiveness of spirometric PFT data growth depends on a number of factors: nosology and disease's severity, sensitivity to certain bronchodilators, age of patient and others. These factors determine individual regimes of HAT, as well as possibility and feasibility of its combination with other medicamental and non-medicamental influences $[18,19,27,51]$. 
For example, in patients with persistent mild and moderate bronchial asthma, most effective is usage of two consecutive (without a break) 30-minute procedures of HAT, which increases the intensity of haloaerosol influence and allows to reduce the course of treatment to $15-16$ procedures [27]. In severe asthma, it is more expedient to use standard method of treatment - daily 45-60 minutes procedures of HAT, 18-20 for treatment course. At the same time, in patients with COPD, in order to prevent severe balneal reactions, it is recommended to take a break (3-5 hours) between two 30-minute procedures. To intensify the immunorehabilitation effect in COPD patients, treatment complexes with additional prescription of medicines with immunomodulatory and antiviral activity have been developed $[19,53,54]$.

In children with bronchial asthma, recurrent bronchitis or category of "frequently ill children", treatment complexes using singlet oxygen therapy, vibroacoustic therapy, laser therapy, interference therapy, etc. are proposed. However, in all cases it is necessary to follow scientifically substantiated approaches to the differentiated prescription of treatment complex, accounting the disease's peculiarities and existing modifying factors [20,39].

It should be emphasized that for patients with bronchial asthma and COPD, the course of HAT does not automatically cancel basic therapy. During HAT, basic medicamental treatment and dosage of some medicines may be changed, but this question is decided individually. According to some researchers, HAT plays the role of additional (complementary) therapy [48,55], which improves the effectiveness of complex treatment and patients quality of life.

Increase in spirometric PFT data is naturally accompanied by improvement of gas exchange in lungs and decrease of tissue hypoxia. This can be evidenced by previous results, which were obtained in rehabilitation treatment of convalescents after COVID-19. Under the influence of HAT, saturation increased from $95,7 \pm 0,39 \%$ to $97,8 \pm 0,36 \%(p<0,001)$ and distance that patients passed in 6-minute test increased from $462,4 \pm 6,15 \mathrm{~m}$ to $494,2 \pm 6,35 \mathrm{~m}(\mathrm{p}<0,001)$. These changes were simultaneously accompanied by significant decrease in dyspnea severity before and after test, which was determined by Borg scale and pulse frequency. This fact confirms improvement of gas exchange in lungs under the influence of HAT, recovery/improvement of functional state of patients and opens prospects for a new direction in HAT usage - rehabilitation after COVID-19.

All above aspects of the mechanism of haloaerosoltherapy influence lead to a decrease in the intensity of oxidative stress and correction of metabolic disorders, which is especially relevant for patients with COPD [46,56-58]. M.Gabor et al. (2018) [46] studied the intensity of lipid peroxidation (LPO) in blood, saliva and condensate of exhaled air in COPD patients, as well as main enzymes of antioxidant defense (AOD) in red blood cells under the influence of different regimes of HAT. It was showed that by the end of treatment course the intensity of LPO decreased. In the condensate of exhaled air this dynamics was more pronounced, and was accompanied by certain recovery of AOD activity. Expressiveness of these changes depended on the applied HAT regime $[45,46]$. Decrease in the intensity of oxidative stress was also observed in convalescents after community-acquired pneumonia and in children with recurrent bronchitis and frequently ill children [59-61].
Decrease of inflammatory process activity in bronchi contributes to the reduction of systemic inflammation activity, which is characteristic for COPD patients. Studies have shown that course of HAT in COPD patients leads to predominant lowering of pro-inflammatory cytokines production, which leads to certain correction of balance between pro- and antiinflammatory cytokines [47].

Lowering the proinflammatory cytokines levels with certain recovery of cytokine balance under the influence of HAT were also observed in convalescents after community-acquired pneumonia and in the group of frequently ill children, as well as in children with recurrent bronchitis [62-65]. It was also noted that in patients with persistent bronchial asthma, recovery of cytokine balance is accompanied by reduction of eosinophils number and decrease in total $\operatorname{IgE}$ level [66]. This makes it possible to consider inhibition of inflammatory activity, both local and general, as very important component of the mechanism of haloaerosoltherapeutic influence.

It is sanitizing effect of HAT and reducing the activity of local and systemic inflammatory processes that indirectly determine improvement of immunological reactivity and increase the resistance of organism. Improvement of nonspecific resistance of organism is noted by many researchers at different diseases in adults and children (chronic bronchitis, bronchial asthma, COPD, recurrent bronchitis and the recovery period of frequently ill children, etc.). Increase of phagocytic activity of neutrophils and monocytes [47,67-70], improvement of mucosal immunity indices are indicated [19,42,43,71]. Elevation of phagocytes microbicidity is noted, which is associated with decrease in endotoxicosis at patients with bronchial asthma and COPD [57].

Detailed studies of cellular immunity in different contingents of patients were also performed: bronchial asthma, chronic bronchitis and COPD, convalescents after community-acquired pneumonia, children with bronchial asthma, recurrent bronchitis and frequently ill children [10,19,39,67,69,71]. In all cases, there were positive changes in studied indices (increase in T-lymphocytes number in cases of their low level, improvement/rebalancing of ratio between helpers and suppressors, elevaton of natural killers number, etc.). Expressiveness of this dynamics depended on peculiarities of changes in certain nosology, disease's severity and other modifying factors. It is noted that dynamics of cellular immunity denotes the direction of immune response towards normalization with recovery of appropriate relationships between cellular subpopulations.

Study of apoptosis processes of lymphocytes and neutrophils, which were conducted in COPD patients, is of particular significance. Under the influence of HAT, there was a decrease in readiness to lymphocytes' apoptosis, which is the basis for recovery of their amount and subpopulation composition [72]. At the same time, there was decrease in expression of activation markers on neutrophils, which was associated with an elevation of intensity of their apoptosis [47]. This contributes to the inhibition of neutrophilic inflammation in bronchial tree and, from the standpoint of pathogenesis, substantiates usage of HAT in rehabilitation treatment of COPD patients.

Improvement of non-specific protection indices in combination with correction of cellular immunity make it possible to talk 
about immunorehabilitation effect of HAT, which results in stabilization of patients status and improving the clinical course of disease and patients quality of life in general at chronic pathology, or health improving in cases of recovery after acute or recurrent disease.

Long-term results of HAT use in patients with bronchopulmonary pathology. The effectiveness of HAT as method of pulmonary rehabilitation is evidenced by evaluation of long-term treatment results. In particular, 360 patients with moderate bronchial asthma were assessed for quality of life before and immediately after course of HAT using the EQ-5D$5 \mathrm{~L}$ questionnaire. Before treatment, respondents rated the quality of life on average by $54,7 \pm 4,1$ points, and after it $62,7 \pm 2,3$ points $(p<0,05)$, which indicates significant improvement in this index [73]. In addition, efficacy of treatment during a year after HAT was studied using questionnaire and results were compared with the status of patients during a year before treatment. It was found that after HAT the disease's course significantly improved. This was manifested by reduction of asthmatic attacks frequency more than in 2 times, frequency of outpatient treatment - in 2 times, and inpatient - by $45 \%$, which resulted in a significant decrease of incapacity days number (42\%) [74].

Similar regularities were observed in COPD patients [75]. Duration of remission in these patients amounted from $6,3 \pm 0,15$ to $10,2 \pm 0,68$ months, depending on the disease's severity and used treatment regime. Best results were obtained when treatment with increased haloaerosol intensity (two 30minute procedures per day) was used. Weinreich et al (2014) also noted improving the quality of life under the influence of HAT in COPD patients [52].

According to various authors, especially indicative are results of HAT usage in children, at which effectiveness of treatment immediately after HAT is more than 95\% [20,39,76]. Immediate results of treatment were confirmed by observation data in the remote period for one year after course of rehabilitation treatment [77]. Thus, in frequently ill children, frequency of ARD during a year after HAT decreased from $4,6 \pm 0,24$ to $3,4 \pm 0,27$ episodes per year $(p<0,01)$, and duration of one episode of disease decreased from $9,67 \pm 0,9$ days to $6,9 \pm 0,5$ days $(p<0,02)$. The number of days during which the child did not attend school decreased from $26,8 \pm 1,5$ to $19,0 \pm 1,5$ days $(p<0,01)$. Similar regularities are observed in children with bronchial asthma or recurrent bronchitis, which allowed to recommend HAT as method of rehabilitation and secondary prevention in children.

The usage of HAT in upper respiratory tract pathology. In addition to the pathology of broncho-pulmonary system, HAT is widely used in upper respiratory tract diseases of both allergic and infectious-inflammatory origin [33,78-81]. These studies are close to clinical investigations that were conducted in group of frequently ill children. In allergic rhinosinusitis, in addition to positive dynamics of clinical symptoms and rhinoscopic picture, there was lowering of histamine level in blood and reduction of eosinophils number in peripheral blood taken from nasal sinuses $[78,79]$.

In patients with subobstructive adenotonsillar hypertrophy after 10 seances of HAT there was a decrease in severity of adenoids and/or hypertrophy of tonsils. This process was accompanied by hearing improvement at almost half of patients [80]. Besides this, it was found that HAT helps to improve morphofunctional status and protective properties of oropharyngeal mucosa $[42,43]$, as well as promotes recovery of mucociliary transport speed [81].

Differences between HAT and "salt rooms (caves)". Once again, we want to emphasize differences between HAT, as method of treatment with existing curative factor and proven mechanism of therapeutic effect and all varieties of "salt rooms", "caves", "live air rooms", etc., where only "medical design" is present in form of walls decoration, lighting, musical accompaniment, etc. Comparative characteristics of these methods are given in table 1.

Table 1 Comparative characteristics of the curative factors of speleotherapy (ST), haloaerosoltherapy (HAT) and «salt rooms» (SR)

\begin{tabular}{|c|c|c|c|c|}
\hline $\begin{array}{c}\text { Main } \\
\text { characteristics }\end{array}$ & ST & $\begin{array}{c}\text { HAT } \\
\left(<15 \mathrm{mg} / \mathrm{m}^{3}\right)\end{array}$ & $\begin{array}{c}\text { HAT } \\
\left(>15 \mathrm{mg} / \mathrm{m}^{3}\right)\end{array}$ & $\begin{array}{l}\text { «Salt } \\
\text { room» }\end{array}$ \\
\hline $\begin{array}{l}\text { Concentration } \\
\text { of the } \\
\text { haloaerosol }\end{array}$ & $\begin{array}{c}4- \\
24 \mathrm{mg} / \mathrm{m}^{3}\end{array}$ & $4-12 \mathrm{mg} / \mathrm{m}^{3}$ & $\begin{array}{l}16 \mathrm{mg} / \mathrm{m}^{3} \\
\text { and more }\end{array}$ & $\begin{array}{l}<2 \mathrm{mg} / \mathrm{m}^{3}, \\
\text { in the } \\
\text { majority of } \\
\text { cases } \\
<1 \mathrm{mg} / \mathrm{m}^{3}\end{array}$ \\
\hline $\begin{array}{l}\text { Large-grained } \\
\text { haloaerosol }\end{array}$ & + & ++ & +++ & - \\
\hline $\begin{array}{l}\text { Medium- } \\
\text { grained } \\
\text { haloaerosol }\end{array}$ & + & +++ & +++ & - \\
\hline $\begin{array}{l}\text { Small-grained } \\
\text { haloaerosol }\end{array}$ & +++ & +++ & +++ & $+(<1 \mu \mathrm{m})$ \\
\hline $\begin{array}{l}\text { Low microbial } \\
\text { content in the } \\
\text { air }\end{array}$ & +++ & + & ++ & - \\
\hline $\begin{array}{l}\text { Hypoallergic } \\
\text { medium }\end{array}$ & +++ & + & + & - \\
\hline $\begin{array}{l}\text { Isolation from } \\
\text { the } \\
\text { environment }\end{array}$ & +++ & - & - & - \\
\hline $\begin{array}{l}\text { Possibility for } \\
\text { modeling the } \\
\text { aerosol } \\
\text { parameters }\end{array}$ & - & +++ & +++ & - \\
\hline \multicolumn{5}{|c|}{ Fields of use: } \\
\hline $\begin{array}{l}\text { Health } \\
\text { improvement }\end{array}$ & \pm & ++ & \pm & + \\
\hline Treatment & +++ & +++ & +++ & - \\
\hline $\begin{array}{l}\text { Secondary } \\
\text { prophylactics }\end{array}$ & +++ & +++ & +++ & - \\
\hline $\begin{array}{l}\text { Duration of } \\
\text { the treatment } \\
\text { procedure: } \\
\text { - for adults } \\
\text { - for children }\end{array}$ & $\begin{array}{l}5-12 \text { hours } \\
3-5 \text { hours }\end{array}$ & $\begin{array}{l}30-60 \mathrm{~min} \\
15-30 \mathrm{~min}\end{array}$ & $\begin{array}{l}30-60 \mathrm{~min} \\
15-30 \mathrm{~min}\end{array}$ & $\begin{array}{c}\text { not } \\
\text { regulated } \\
(1-10 \text { hours } \\
1-10 \text { hours })\end{array}$ \\
\hline $\begin{array}{l}\text { Duration of } \\
\text { the course of } \\
\text { treatment }\end{array}$ & $\begin{array}{c}18-25 \\
\text { procedures }\end{array}$ & $\begin{array}{c}18-22 \\
\text { procedures }\end{array}$ & $\begin{array}{c}16-20 \\
\text { procedures } \\
\text { (for adults) } \\
13-18 \\
\text { (for } \\
\text { children) }\end{array}$ & $\begin{array}{c}\text { not } \\
\text { regulated } \\
\text { (from } 5 \text { to } \\
20 \\
\text { procedures) }\end{array}$ \\
\hline
\end{tabular}

As can be seen from the table in "salt rooms" main acting factor - haloaerosol in adequate concentration and dispersion - is not present. So these technics can only be used as spa procedure.

However, in general, questions of unified approaches to haloaerosoltherapy procedures, parameters of created haloaerosol environment, number of procedures for course of treatment and regime of their prescription are still not approved. This may be ground for discrediting this method. As 
long as there is no clear understanding in medical community of what haloaerosoltherapy exactly is, which criteria of haloaerosol environment and treatment process in general must be complied, precise control of relevant specialists over all business proposals such as "salt rooms" will be ensured - the clear distinction between method of treatment, spa procedure, or simply profanation, will not be achieved. Necessity for differentiation of various types of halotherapy is pointed out by other researchers [12,82]. In this regard, it should be emphasized that usage of the term "halotherapy" today should be considered as incorrect. When using term "halotherapy" there is no clear differentiation of the nature of used influence, and this is the basis for discreditation of HAT as method of treatment.

Analysis of incorrect usage of HAT and doubtful (negative) assessments of its effectiveness. One of the reasons for skepticism about HAT is its incorrect use in some cases, when, based on the mechanism of therapeutic effect, there are no grounds for its prescription. In particular, there are cases when in advertising publications concerning usage of halotherapy in form of "salt rooms" (without specifying presence of haloaerosol) for patients with arterial hypertension and cardiovascular disease are indicated. This is completely not justified by mechanism of therapeutic effect of haloaerosols. Moreover, presence of arterial hypertension and coronary heart disease with severe clinical manifestations is one of contraindications for HAT.

Along with that, in the publication of Matsegora NA et al [83] effectiveness of HAT in patients with mild and moderate persistent bronchial asthma with concomitant coronary heart disease of I and II functional classes has been evaluated. It was found that complex treatment that included basic therapy of asthma (salmeterol with fluticasone propionate) and HAT contributed to improvement not only of spirographic parameters, but also into positive dynamics of Holter ECG monitoring data in form of significant decrease in mean daily heart rate and frequency of supraventricular extrasystoles. Authors explain this fact by reducing use of short-acting $\beta_{2}$-agonists and by positive influence on autonomic nervous system. However, in any case, presence of concomitant cardiovascular pathology requires balanced personalized approach to HAT usage. By the way, authors of the above-mentioned work used terms speleotherapy and halotherapy and only detailed analysis of this publication revealed that they used HAT.

An example of incorrect assessment of halotherapy efficiency in COPD patients is the review by R.Rashleigh et al [84]. Authors selected 151 publications for initial analysis, but later narrowed this analysis to 4 publications on formal approach. In particular, authors did not consider works that were not published in English. As a result, they compared data on effects of haloaerosoltherapy (group inhalation of haloaerosol with certain concentration above-ground), which was used in patients beyond exacerbation, haloinhalation therapy, which was carried out using individual inhaler during exacerbation and two publications on speleotherapy in karst caves with no presence of halite. However, these are different methods that cannot be compared. In addition, one of papers on karst cave treatment was published in 1986, when the term COPD was not yet used at all and contained data on patients with chronic bronchitis and bronchial asthma. From these facts, we can conclude that authors do not understand difference between these methods, and their conclusion, although positive, regarding the use, as they affirm, of "halotherapy" cannot be considered correct.

The publication by Agnihotri NT et al. [85] is also incorrect, because authors, without analyzing available scientific researches, believe that halotherapy (without concretisation of what exactly method is used) refers to methods that have profound psychological influence on patients while objective physical benefit of method is absent. Therefore, clear differentiation of halotherapy methods is needed using appropriate terms that clearly indicate the main factor, which is used.

Doubtful publications on double-blind placebo-controlled studies also do not contribute to the approval of HAT as method of rehabilitation treatment $[48,76]$. Such researches must include placebo, in this case in form of aerosol, which by external signs completely corresponds to tested therapeutic factor, but does not contain it. Patients perceive haloaerosol in therapeutic concentrations (more than $2-3 \mathrm{mg} / \mathrm{m}^{3}$ ) visually and organoleptically (salty taste). In addition, according to Polish researchers, list of substances that can be used to create such aerosols is limited. Even evaporated Dead Sea salt is not suitable for creation of such haloaerosols [11]. The question is, what was used as placebo? None of the above publications contains such data, and without this information, adequacy of these researches is questionable.

\section{Conclusions}

1. Usage of the term "halotherapy" for all methods that use halite (mineral of sodium chloride) or treatment in mine workings or karst caves is incorrect. This determines necessity for stop using this term. It is necessary to differentiate clearly applied methods of treatment using terms that reflect the essence of therapeutic effect.

2. Haloaerosoltherapy should be considered as method of respiratory rehabilitation with proven mechanism of action and effectiveness, as clearly is defined the main active factor - rock salt aerosol, which has certain concentration $\left(>2-3 \mathrm{mg} / \mathrm{m}^{3}\right)$ and dispersion with presence of small-, medium- and largegrained phase. Haloaerosol is obtained using specific devices halogenerators. Haloaerosol parameters are controlled in dynamics of procedures and can vary within certain limits while used for different nosologies.

3. Basis of the mechanism of haloaerosol influence at its appropriate concentration and dispersion is hyperosmolar stimulus that provides enhanced drainage function and sanitizing effect, which causes further changes at local and systemic levels.

4. Main requirements to the technology of haloaerosoltherapy procedures, their duration and number are defined, certain medical complexes of its use with other non-medicamental and medicamental means are developed. Effectiveness of haloaerosoltherapy after course of treatment and in remote period has been proven.

\section{Acknowledgments}

This work was carried out within the scientific project of Government Institution "The Scientific-practical Medical Centre "Rehabilitation" Health Ministry of Ukraine": "Some regularities of comorbid conditions development in patients 
with chronic obstructive pulmonary disease and possibilities for their non-medicamental correction" (2020-2022; Reg. Number 0120U101711). The research was funded by the Ministry of Health of Ukraine at the expense of the State Budget..

\section{References}

1. Lemko OI, Lemko IS Speleotherapy, halotherapy, haloaerosoltherapy: definitions, mechanisms of influence, perspectives of usage (part I). Asthma and Allergy. 2017; 3: 50-63. URL: http://www.ifp.kiev.ua /doc/journals/aa/17/pdf17-3/50.pdf

2. Lemko OI, Lemko IS Speleotherapy, halotherapy, haloaerosoltherapy: definitions, mechanisms of influence, perspectives of usage (part II). Asthma and Allergy. 2018; 3: 34-41. URL: http://www.ifp.kiev.ua/doc/journals/aa/18/pdf18-3/34.pdf

3. Gorbenko PP, Bogdanova AV, Ivanova PA, Boytsova EV. Halotherapy in the treatment of allergic respiratory diseases in children: Methodological writing. Leningrad 1991; 10 p. URL: http://xn----itbeeebwndu.xn-plai/images/pdf/publ 5.pdf

4. Khan MA, Kotenko KV, Korchazhkina NB, Chervinskaya AV, Mikitchenko NA, Lyan NA. The promising directions for the further development of halotherapy in pediatric medicine. Problems of Balneology, Physiotherapy and Exercise Therapy. 2016; 6: 61-64. DOI: 10.17116/kurort2016661-6

5. Czajka K, Sziwa D, Drobnik M, Latour T. Porównanie własnosci mikroklimatu i aerozoli w wyrobiskah kopalnianych i naziemnych grotach solnych. Balneologia Polska. 2006; 3: 176-81.

6. Bar-Yoseph R, Kugelman N, Livnat G et al. Halotherapy as asthma treatment in children: A randomized, controlled, prospective pilot study. Pediatr. Pulmonol. 2017; 52(5): 580-7. DOI: 10.1002/ppul.23621.

7. Lemko IS, Lemko OI, Haysak MO. Haloaerosoltherapy method of treatment or spa-procedure? Acta Balneologica. 2015: 57(1)(139); 28-33.

8. Kazanskyy YuP, Dymkyn VA, Lemko IS, Lyubushko GI, Torokhtin MD. Geological aspects of speleotherapy (on the example of the medical mine of the settlement Solotvino of the Transcarpathian region of the Ukrainian SSR). Novosybyrsk 1986; 79 p. URL:https://www.geokniga.org/bookfiles/geoknigageologicheskie-aspekty-speleoterapii-na-primerelechebnoy-shahty-pos-solotvino.pdf

9. Chervinskaya AV. Mechanisms of action and possible therapeutic applications of controlled halotherapy. The hospital. 2012; 2-3: 189-200. URL: http://xn---itbeeebwndu.xn--p1ai/images/pdf/nauka_5.pdf

10. Crisan-Dabija R, Minarescu T. Halotherapy and Buteyko Breathing Technique - a possible successful combination in relieving respiratory symptoms. GJRA. 2017; 3(11): 673-4. URL:https://www.worldwidejournals.com/globaljournal-for-research-analysis-

GJRA/fileview/May 2017 1495031752 196.pdf

11. Ponikowska I, Latour T, $\bar{C}$ hervinskaya $\bar{A}$, Cojnowski J, Blaszkiewicz B, Szmurlo W. Badania właściwości fizyczno-chemicznych suchego aerozolu solnego w komorze naziemnej. Balneologia Polska. 2009,
52(2)(116): 92-100. URL:https://chervinskaya.com/wpcontent/uploads/pdf/10-

Balneologia Physico chem DSA article pl.pdf

12. Zajac J, Bojar I, Hēlbin J, Kolarzyk E, Owoc A. Salt caves as simulation of natural environment and significance of halotherapy. Ann Agric Environ Med. 2014; 21(1): 124-7. URL: file://C:/Users/Admin/Downloads/

Salt $\% 20$ caves $\% 20$ as $\%$ 20simulation $\% 20(1)$.pdf

13. Torokhtin MD, Zheltvaj VV, Torokhtin AM. Device for obtaining aerosol of table salt: Author's certificate of the USSR № 1140296: IPC A61M13 / 00; application №3465166; priority 05.07.1982; registered in the State Register of Inventions of the USSR, October 15, 1984; publ. 15.02.1985, Bull. 1985; 6 .

14. Tarnay AA, Kirilenko VK, Sharkan JP, Lemko IS, Lemko OI, inventors; Tarnay AA, assignee. Aerosol generator. Ukraine patent 97869. 2012 Mar 26. Bull. 2012; 6: 4 p. URL: https://base.uipv.org/searchINV/search.php?action= viewdetails\&IdClaim $=171327$

15. Lemko IS, Khobzej MK, Sharkany JP, Lemko OI. New possibilities for haloaerosol media creation in their medical use. Asthma and Allergy. 2010; 3-4: 45-7. URL: http://www.ifp.kiev.ua/doc/journals/aa/10/pdf10-34/45.pdf

16. Kosyachenko GE, Tyshkevych GI, Sidorova NV. The content of salt aerosol in the air of above-ground haloclimatic chambers of different types. Speleotherapy in Solotvino salt mines: Materials of the International Symposium of Allergists "30 years of the Ukrainian Allergological Hospital"; Solotvino 2006; 24-5.

17. Lemko IS, Lemko OI. Speleo- and haloaerosoltherapy in Transcarpathia - formation, present, prospects. Current questions of balneology, physiotherapy and medical rehabilitation: Works. Yalta (Aktualnye voprosy kurortolohyy, fyzyoterapyy y medytsynskoy reabylytatsyy: Trudy). 2013; XXIV: 132-8.

18. Lemko IS. Clinical-pathogenic and chronobiologic substantiation of differential speleotherapy and guided haloaerosoltherapy in the rehabilitation treatment of bronchial asthma patients [abstract of the dissertation for the Doctor of Medical Sciences degree]. Odesa 2008; 43 p. URL:http://www.disslib.org/kliniko-patohenetychneta-khronobiolohichne-obruntuvannja-

dyferentsiyovanoho.html

19. Lemko OI. Clinical-pathogenic substantiation of haloaerosoltherapy and immunorehabilitation principles in the rehabilitation of chronic obstructive pulmonary disease patients [abstract of the dissertation for the Doctor of Medical Sciences degree]. Yalta 2011; 48 p. URL:http://repository.ldufk.edu.ua:8080/bitstream/34606 $048 /$ $26676 / 1 / \% \mathrm{~d} 0 \% 9 \mathrm{~b} \% \mathrm{~d}$ 0\%b5\%d0\%bc\%d0\%ba\%d0\%be_avtoref_2011.pdf

20. Lukashuk SV. Clinical-pathogenetic substantion of haloaerosoltherapy in rehabilitation treatment of children with recurrent bronchitis and frequently ill children [abstract of the dissertation for the degree of Candidate of Medical Sciences]. Kharkiv 2016; 22 p. URL:https://rive.google.com/file/d/0B8ieRnNnetyTRklI 
cy0yO

\section{H7WELU2D8hRh04sO5zOu4Q}

21. Lemko I, Lukashchuk S. The usage of haloaerosoltherapy in the rehabilitational treatment of children with recurrent bronchitis. Balneo Research Journal. 2015; 6(2): 60-4. DOI: http://dx.doi.org/10.12680/balneo.2015.1087

22. Lemko OI, Lemko IS. New technologies of haloaerosoltherapy at asthmatic patients. Balneo Research Journal. 2013; 4(1): 49-52. DOI: http://dx.doi.org/10.12680/balneo.2013.1042

23. Sharkan JP, Zhytov NB, Lemko IS, Sichka MY, Chonka YV, Mykulanynets SV, Kozych LI, Lemko OI., inventors; Uzhgorod State University, assignee. The method of continuous control of the concentration of aerosol particles. Ukraine patent 36016 A. 2001 Apr 16. Bull. 2001; 3: 4 .

24. Sharkany JP, Zhytov NB, Sichka MJ, Lemko I, Pintye J, Chonka Ya. "Optical measurement of medical aerosol media parameters", Proc. SPIE 4129, Subsurface Sensing Technologies and Applications II, (6 July 2000). DOI:https://doi.org/10.1117/12.390670

25. Torokhtin MD, Zheltviy VV, Kazankevich VP, Zadorozhna TO, Maltseva OB. Instruction to the method of treatment of patients with bronchial asthma in conditions of artificial microclimate chambers. Uzhgorod $1985 ; 10 \mathrm{p}$.

26. Tishkevich GI, Kosyachenko HE, Solonovich MP. Optimization of general microbiological semination leves of air environment in above-ground haloclimatic chambers. Speleotherapy in Solotvino salt mines: Materials of the International Symposium of Allergists "30 years of the Ukrainian Allergological Hospital"; Solotvino 2006; 22-3.

27. Lemko II, Lemko OI. Haloaerosoltherapy: its state of today and its prospects. Medical Rehabilitation, Balneology, Physiotherapy. 2007; 4(52): 9-11.

28. Yavorskiy K. Speleotherapy of respiratory diseases in the conditions of salt artificial microclimate. Cartea Moldovei, Kishinev 2004; 98 p.

29. Simionca Ju, Grudnicki N, Lazarescu $\mathrm{H}$ et al. The "Halotherapy salon with salt mine artificial environment" from NIRPHMB and particulaties of Halotherapeutic factors (project/contract 42120/2008 in RDI-2 National plan, Romania). Balneo Research Jornal. 2013;4(2). Supliment: Conferinta Natională de Balneologie, Slanic Moldova, 29 Mai-01 Junie, 2013 (Volum de Rezumate): 28-30. URL: http://bioclima.ro/REZ2013.pdf

30. Obruch AK, Filipchuk SK. Complex health improvement of children with respiratory diseases using halotherapy method in "Zeleny Bor". Speleotherapy in the treatment of chronic bronchopulmonary diseases: Proceedings of the Republican Scientific-Practical Seminar in Solegorsk 2001 Sept 27-28, Minsk 2001; 42.

31. Lemko OI, Lemko IS, Sharkanj YP, Sakalosh II. Peculirities of rock salt aerosol media creation for treatment of patients with chronic obstructive pulmonary disease. Herald of Physiotherapy and Health Resort Therapy. 2012; 3: 8-13.

32. Barber D, Malyshev Y, Oluyadi F, Andreev A, Sahniet S. Halotherapy for Chronic Respiratory Disorders: From the
Cave to the Clinical. Altern Ther Health Med. 2020 Aug 20: AT6413.

URL:

https://pubmed.ncbi.nlm.nih.gov/32827399/

33. Endre L. Theoretical basis and clinical benefits of dry salt inhalation therapy. Orv. Hetil. 2015; 156(41): 1643-52. DOI: $10.1556 / 650.2015 .30267$.

34. Lemko OI. Approaches to differentiated use of haloaerosoltherapy in patients with moderate chronic obstructive pulmonary disease. Ukrainian Medical Almanac. 2009; 12(2 Suppl.): 132-4.

35. Lemko OI. Efficiency of differential haloaerosoltherapy at patients with severe COPD (clinical and functional investigations). Bukovinian Medical Herald. 2010; 14(1): $55-8$.

36. Goncharuk SF, Fedorchuk TI, Kasyanenko AV. Specific characteristics of spirographic data dynamic changes in children with bronchial asthma during the treatment course in aftificial microclimate chamber with salt aerosol. Medical Rehabilitation, Balneology, Physiotherapy. 2006; 3: 20-3.

37. Lukashchuk SV, Mitsyo TV, Moroz HI, Popova VI. Efficiency of haloaerosoltherapy in recovery treatment of children with recurrent respiratory infections. Asthma and Allergy. 2018; 2: 52-3. URL: http://www.ifp.kiev.ua/doc/ journals/aa/18/pdf18-2/52.pdf

38. Slyvko RY, Sukhan VS. Recovery of regulatory mechanisms in patients with chronic obstructive pulmonary disease using aerosoltherapy. Bukovinian Medical Herald. 2000; 3: 150-4.

39. Goncharuk SF. Rehabilitation treatment of children with bronchial asthma. "Astroprint", Odessa 2004; 200 p.

40. Maierean A, Ciumarnean L, Alexescu TG et al. Complementary therapeutic approaches in asthma. Balneo Research Journal. 2019; 10(3): 204-12. DOI: http://dx.doi.org/10.12680/balneo.2019.258

41. Chervinskaya AV, Kvetnaya AS, Korzhenevskaya TB. Effect of the dry sodium chloride aerosol on physiological properties of Streptococcus pneumoniae and the mucosa epithelium at the experiment. Clinical and Laboratory Council. 2009; 3: 72-7. URL:https:/www.1spbgmu.ru/images/home/universitet/iz datelstvo/Kliniko-lab_konsil/2009/klk3282009.pdf

42. Khan MA, Chervinskaya AV, Mikitchenko NA. The effect of halotherapy on mucosal immunity, cytobacteriological and morphofunctional state of oropharyngeal mucous membrane in children with acute respiratory disease. (Part I). Allergology and Immunology in Pediatrics. 2011; 1: 33-5. URL:file:///C:/Users/Admin/Downloads/dinamikapokazateley-mukozalnogo-immunitetatsitobakteriologicheskogo-i-morfofunktsionalnogosostoyaniya-slizistoy-rotoglotki-u-chasto-boleyuschihshkolnikov-pod-vliyaniem-galoterapii-chast-1.pdf

43. Khan MA, Chervinskaya AV, Mikitchenko NA. The effect of halotherapy on mucosal immunity, cytobacteriological and morphofunctional state of oropharyngeal mucous membrane in children with acute respiratory disease. (Part II). Allergology and Immunology in Pediatrics. 2011; 2: 30-3. URL:file://C:/Users/Admin/Downloads/dinamika- 
pokazateley-mukozalnogo-immuniteta-

tsitobakteriologicheskogo-i-morfofunktsionalnogosostoyaniya-slizistoy-rotoglotki-u-chasto-boleyuschihshkolnikov-pod-vliyaniem-galoterapii-okonchanienachalo-v-1-za-2011.pdf

44. Gabor ML, Lemko OI, Reshetar DV, Tymkanich OM. Stabile metabolites of nitric oxide and their correction under influence of haloaerosoltherapy in patients with chronic obstructive pulmonary disease. Collection of Scientific Works of Staff Members of NMAPE. 2007; 16(2): 591-5.

45. Gabor ML, Lemko OI, Reshetar DV, Tymkanich OM. Correction of metabolic disturbances in patients with chronic obstructive pulmonary disease. Collection of Scientific Works of Staff Members of NMAPE. 2010; 19(1): 351-6.

46. Gabor ML, Reshetar DV, Kopolovets TI. Changes in oxidative homeostasis in patients with chronic obstructive pulmonary disease under the influence of haloaerosoltherapy. Speleotherapy and its Artificial Analogues in Ukraine: Beginnings and Prospects: Materials of the scientific-practical conference, devoted to the 50th anniversary of speleotherapy in Ukraine; 2018 May 24-25, Solotvino 2018; 45-7

47. Lemko OI, Reshetar DV, Vantyukh NV, Kopinets II. Haloaerosoltherapy at chronic obstructive pulmonary disease: mechanisms of treatment influence. Asthma and Allergy. 2018; 2: 34-6. URL: file://C:/Users/Admin/Downloads/astm_2018_2_12\%20( 1).pdf

48. Hedman J, Hugg T, Sandell J, Haahtela T. The effect salt chamber treatment on bronchial hyperresponsiveness in asthmatics. Allergy. 2006; 61: 605-10. DOI:10.1111/j.1398-9995.2006.01073.x

49. Sandell J, Hedman J, Saarinen K, Haahtela T. Salt chamber treatment is ineffective in treating eosinophilic inflammation in asthma. Allergy. 2013; 68(1): 125-7. DOI:10.1111/all.12061

50. Zając D, Russjan E, Kostrzon M, Kaczyńska K. Inhalations with Brine Solution from the 'Wieliczka' Salt Mine Diminish Airway Hyperreactivity and Inflammation in a Murine Model of Non-Atopic Asthma. Int. J. Mol. Sci. 2020; 21(13): 16 p. DOI: https://doi.org/10.3390/ijms21134798

51. Lemko OI, Lemko IS, Kopinets II. The differential regimes of haloaerosoltherapy in recovery treatment of patients with persistent bronchial astma: clinical and functional aspects. Medical Rehabilitation, Balneology, Physiotherapy. 2012; 3: 15-9.

52. Weinreich UM, Nilsson T, Mylund L, Christiansen HT, Schantz Laursen B. Salt halo therapy and saline inhalation administered to patients with chronic obstructive pulmonary disease: a pilot study. J Palliat Care Med. 2014; 4(4): 5 p. DOI:10.4172/2165-7386.1000185

53. Lemko OI. Using of proteflasid in complexes restoration treatment of patient with cronic obstructive lung disease. Herald of physiotherapy and health resort therapy. 2009; 15(3): 15-7.

54. Lemko OI, Reshetar DV, Gabor ML, Bolohovska VA, Lemko IS. The complex restorative treatment of patients with stage I COPD using immunomodulator. Ukr. Pulmonol. J. 2012; 3: 38-43. URL: http://www.ifp.kiev.ua/doc/journals/upj/12/pdf123/38.pdf

55. Potyazhenko MM, Ishcheikin KY, Nastroga TV, Sokolyuk NL, Kitura OYe, Gorodnytska IM. Optimization of pathogenetic therapy in patients with chronic obstructive lung disease. Wiad Lek. 2020; 73(4): 773-6. DOI: 10.36740/WLek202004128

56. Reshetar DV. Non-medicamental treatment as the method of correction the oxidative homeostasis in patients with chronic obstructive pulmonary disease. Medical Rehabilitation, Balneology, Physiotherapy. 2012; 3: 23-5.

57. Farkhutdinov UR, Abdrakhmanova LM, Farkhutdinov SU. Effects of halotherapy on free radical oxidation in patients with lung diseases. Pulmonologiya. 2008; 1: 2932. DOI:https://doi.org/10.18093/0869-0189-2008-0-129-32

58. Chervinskaya AV, Konova OM, Khan MA. Halotherapy for prevention and medical rehabilitation in pediatric health care. Current Pediatrics. 2017; 16(5): 406-12. DOI:https://doi.org/10.15690/vsp.v16i5.1805

59. Lemko OI, Gabor ML, Reshetar DV, Tymkanych OM. Effectiveness of haloaerosoltherapy on the indices of lipids peroxidation and antioxidant protection at patients with community acquired pneumonia. Acta Balneologica: XV International Symposium of Speleotherapy, Wieliczka 2014, Poland. 2014; LVI(3)(137): 157.

60. Gabor ML, Lemko OI, Reshetar DV, Tymkanich OM. Influence of the recovery treatment on the indices of lipid peroxidation, antioxidant protection and endogenous intoxication at frequently ill children and children with recurrent bronchitis. 41st ISMH World Congress (19th21th May, 2016): Abstracts book. Balneo Research Journal. 2016; 7(2): 102 . URL: http://bioclima.ro/ABSTRACTS\%20VOLUME.pdf

61. Gabor ML, Reshetar DV. Non-medicamental treatment as a method of correction of oxidative homeostasis in children with recurrent bronchitis and frequently ill children beyond the acute period. Problems of Clinical Pediatrics. 2016; 3-4: 128-133. URL: file://C:/Users/Admin/Downloads/pkp_2016_3-4_24.pdf

62. Lemko OI, Reshetar DV, Kopolovets TI. Cytokine profile in patients with community-acquired pneumonia under the influence of rehabilitation treatment. Medical Rehabilitation, Balneology, Physiotherapy.2015; 1: 1620.

63. Gabor ML, Kopolovets TI, Pavlovich GM, Lemko OI. The changes of cytokines levels in patients with community acquired pneumonia under the influence of haloaerosoltherapy. Balneo Research Journal. 2013 (Supl); 4(2): 24-5. URL: http://bioclima.ro/REZ2013.pdf

64. Lemko OI, Lukashchuk SV, Kopolovets TI. Changes of the inflammation activity in frequently ill children and patients with recurrent bronchitis influenced by rehabilitation treatment. Perinatology and pediatric. Ukraine. 2017; 3: 97-101. URL: file://C:/Users/Admin/Downloads/PIP_03_2017_web\%2 $0(1) . p d f$ 
65. Lemko OI, Lukashchuk SV, Kopolovets TI. Changes of the cytokine profile in children with recurrent bronchitis under the influence of recovery treatment. Collection of scientific works of staff members of NMAPE. 2018; 29: 362-70.

URL: https://nmapo.edu.ua/zagruzka2/zbornikNMAPO29.pdf

66. Buleza B, Chonca Y. The effect of speleotherapy on individual level of humoral immunity in patients with bronchial asthma. Acta balneologica. 2014;LVI(3)(137):150. URL: file://C:/Users/Admin/Downloads/pkp_2016_3-4_3.pdf

67. Vantyukh NV, Lemko OI, Lukaschuk SV. The influence of imunorehabilitative treatment with the usage of natural and preformed physical factors on cellular immunity at frequently ill children. Problems of Clinical Pediatrics. 2016; 3-4: 5-10. URL: file:///C:/Users/Admin/Downloads/pkp_2016_3-4_3.pdf

68. Lemko OI, Lukashchuk SV, Vantyukh NV, Popadinets MI. The influence of recovery treatment on the immune status of children with recurrent respiratory infections. Zdorov'ye Rebenka. 2017; 12(7): 773-9. DOI: 10.22141/2224-0551.12.7.2017.116182

69. Lemko O., Vantyuh N., Reshetar D. The role of haloaerosoltherapy in immunorehabilitation of convalescents after community acquired pneumonia. Balneo Research Journal. 2015; 6(1): 13-9. DOI: http://dx.doi.org/10.12680/balneo.2015.1080

70. Lazarescu H, Simionca I, Hoteteu M et al. Surveys on therapeutic effects of "halotherapy chamber with artificial salt-mine environment" on patients with certain chronic allergenic respiratory pathologies and infectiousinflammatory pathologies. J Med Life. 2014; 7(Spec Iss 2): 83-7.

URL:file://C:/Users/Admin/Downloads/Surveysontherap euticeffectsofhalotherapychamberwithartificialsaltmineenvironmentonpatientswithcertainchronicallergenicre spiratorypathologiesandinfectious-

inflammatorypathologies.pdf

71. Lemko OI, Lukashchuk SV, Vantyukh NV Haloaerosoltherapy in rehabilitative treatment of children with recurrent bronchitis. Ukr. Pulmonol. J. 2017; 2: 2832.

URL:

http://www.ifp.kiev.ua/doc/journals/upj/17/pdf172/28.pdf

72. Lemko OI, Vantyukh NV. The influence of haloaerosoltherapy on cellular immunity and apoptosis of lymphocytes in patients with chronic obstructive pulmonary disease. Medical Rehabilitation, Balneology, Physiotherapy. 2010; 3: 7-10.

73. Aleksandrovych TA, Chemet OA, Holovatski TA, Bezushko TO. New aspects of study of bronchial asthma patients quality of life under the influence of haloaerosoltherapy. Asthma and Allergy. 2018; 2: 40-1. URL: http://www.ifp.kiev.ua/doc/journals/aa/18/pdf182/40.pdf
74. Lemko IS, Aleksandrovych TA, Holovatski TA. Experience of study of delayed results of treatment of patients with bronchial asthma using haloaerosoltherapy. Asthma and Allergy. 2018; 2: 32. URL: http://www.ifp.kiev.ua/doc/journals/aa/18/pdf18-2/32.pdf

75. Lemko OI. The role of haloaerosoltherapy in improving the «quality of life» in patients with chronic obstructive pulmonary disease. Asthma and Allergy. 2018; 2: 28-9. URL: http://www.ifp.kiev.ua/doc/journals/aa/18/pdf182/28.pdf

76. Chervinskaya AV, Konova OM, Khan MA. Halotherapy for prevention and medical rehabilitation in pediatric health care. Current Pediatrics. 2017; 16(5): 406-12. DOI:https://doi.org/10.15690/vsp.v16i5.1805

77. Lemko OI, Lukashchuk SV, Vantyukh NV. Experience of rehabilitation treatment in children with recurrent bronchitis using haloaerosoltherapy. Asthma and Allergy. 2019; 4: 43-9. DOI: 10.31655/2307-3373-2019-4-43-49

78. Lemko IS, Lemko OI, Polak NI, Kazankevich VP. Perspectives for the use of rock salt aerosols in the combination of allergic rhinosinusitis and obstructive pulmonary disease. Ukrainian balneological journal. 2005; 1,2: 90-4.

79. Polak NI. Treatment of allergic rhinitis using haloaerosoltherapy. Asthma and Allergy. 2018; 2: 46. URL:http://www.ifp.kiev.ua/doc/journals/aa/18/pdf182/46.pdf

80. Gelardi M, Iannuzzi L, Greco Miani A et al. Double-blind placebo-controlled randomized clinical trial on the efficacy of Aerosal in the treatment of subobstructive adenotonsillar hypertrophy and related diseases. Int J Pediatr Otorhinolaryngol. 2013; 77(11): 1818-24. DOI: 10.1016/j.ijporl.2013.08.013.

81. Berest IE. Halotherapy in patients with vasomotor rhinitis after surgical treatment. Problems of Balneology, Physiotherapy, and Exercise Therapy. 2020; 97(4): 31-6. DOI:https://doi.org/10.17116/kurort20209704131.

82. Vladeva E, Panajotova L. Halotherapy - benefits and risks. Scripta Scientific Salutis Publicae, 2018; 4; 18-22. URL:file:///C:/Users/Admin/Downloads/5010-14646-2PB.pdf

83. Matsegora NA, Shkurenko EA. Efficiency of application of speleotherapy in treatment of patients with bronchial asthma in combination with coronary heart disease I-II FC as therapy of holter monitoring of ECG. Asthma and Allergy. 2017; 3: 25-9. URL: http://www.ifp.kiev.ua/doc/journals/aa/17/pdf17-3/25.pdf

84. Rashleigh R, Smith SM, Roberts NJ. A review of halotherapy for chronic obstructive pulmonary disease. Int J Chron Obstruct Pulmon Dis. 2014; 9: 239-46. DOI: 10.2147/COPD.S57511.

85. Agnihotri NT, Greenberger PA. Unproved and controversial methods and theories in allergy/immunology. Allergy Asthma Proc. 2019; 40(6): 490-3. DOI: 10.2500/aap.2019.40.4278. 